CURRENT RESEARCH JOURNAL OF PHILOLOGICAL SCIENCES 2(12):

146-150, December 2021

DOI: https://doi.org/10.37547/philological-crjps-02-12-28

ISSN 2767-3758

(C)2021 Master Journals

Crossref do

81 Google

Accepted19th December, 2021 \& Published 24th December, 2021

\title{
ARGO AS A SOCIALLY LIMITED LEXICAL UNIT
}

\section{Zebiniso Sh. Rakhimova}

Lecturer Termez State University Termez, Uzbekistan

\section{ABSTRACT}

This article discusses Argo as a socially limited lexical unit. The existence of language is related to the way people speak or write. In the process of performing these actions, the linguistic units (in the first place - the sentence) show the ability to express, in addition to the original meaning, such content as confirmation, command, warning, promise. These meanings are the result of the speech activity performed by the speaker. Thus, a speech act is a linguistic address of the speaker to the listener in a certain environment, for a specific purpose.

KEYWORDS: - Lexical unit, certain environment, argon, definition.

\section{INTRODUCTION}

One of the characteristics of colloquial speech is that it uses slang, along with many linguistic phenomena. Argon is a brief phenomenon in Uzbek linguistics. It is limited to a few definitions. In particular, Azim Khodzhiev's "Explanatory Dictionary of Linguistic Terms" describes slang as follows:

Argon (French. Argot-jargon). Artificial languages. A social group is a fictitious language that consists of lexical units that are specific to a category (e.g., students, athletes, thieves, etc.) that others cannot understand.

"Argotisms have a hidden meaning," writes linguist
H. Jamolkhanov.

\section{THE MAIN RESULTS AND FINDINGS}

The 5-volume explanatory dictionary of the Uzbek language describes slang as follows:

Argo [fr. argot-jargon] linguistic term. Artificial languages. The language of a particular social group category (e.g., students, spotters, thieves, etc.) is made up of lexical units that others do not understand.

Some social groups, such as thieves, thugs, and gamblers, have different meanings to words in order to hide their evil intentions and evil intentions from others. they give and use. Such words are called slang. For example, - pul instead of 
CURRENT RESEARCH JOURNAL OF PHILOLOGICAL SCIENCES 2(12):

146-150, December 2021

DOI: https://doi.org/10.37547/philological-crjps-02-12-28

ISSN 2767-3758

(C)2021 Master Journals

\section{Crossref do) 81 Google}

Accepted19th December, 2021 \& Published 24 ${ }^{\text {th }}$ December, 2021

the word loy, o'g'irlamoq instead of the word ovqatlanmoq, o'ldirmoq instead of the word sallasipi olib kelmoq, use the words.

Slang (originally slang for thieves) has been used as professional slang since the 19th century.

Argotisms can be used in conversation for a single methodological purpose. Some groups (it should be noted that this is more the case with youth speech) have also used and continue to use slang in order to maintain their superiority and keep their goals secret from others.

A small socially closed group language that differs from the vernacular but does not have its own phonetics and grammatical system. It is also called artificial language. It is safe to say that Argon is a language of students, athletes, thieves, herdsmen, prisoners, and other social groups that is unique to others. Argon is a mixture of several language elements and, in many cases, a form of speech that is incomprehensible to others.

Argon differs from jargon in that it is somewhat a secret language (a group of languages created specifically for outsiders). Therefore, the name of a particular group is followed by the word slang: ("vorovskoe argo", "argo ofeney"). In the small dictionary of linguist Roberti, the term slang is used as a general term for "criminal language" and as a linguistic term for "non-technical vocabulary used by a particular social group". The etymological origin of argon - "corporation desjueux" - is interpreted as "a group of malicious people". In Roberta, the term slang is given as "incorrect, distorted" or artificial language, and is understood to be intelligible only to certain members. A similar interpretation is found in other French linguists. However, according to the dictionaries of the Larus Library, slang (not slang) is "a set of words and phrases used by people of a certain social and professional group to distinguish them from other social units". The modern French linguist LouisJean Calve, author of 20 Lessons on Argon, gives a broader meaning to the term. According to him, slang is an example of oral language and is rich in neologisms that do not last long. Part of it is oral. According to Calve's concept, there are 20 basic semantic fields, and new slangs are constantly created based on this known scheme. According to the linguist, by studying the basic metaphorical structure of each field, one can understand any unknown slang and create a new slang. Thus, in Calve's study, argon is confirmed as a known wordformation system. The term slang is also found in Brockhaus and Efro's encyclopedic dictionary. But instead of commenting, he quotes from the article "Language of Thieves". This, in turn, indicates that the term is synonymous with that unit. As a result, various researchers are expanding the lexical meaning of the term. For example, O.S. Akhmanova's dictionary states that slang is the same thing as slang, except that it is "devoid of manipulative and discriminatory tone". However, many scholars interpret argon as a means of speech belonging to the lower strata of society. There is a sharp philological debate about the properties of modern argon; the question of whether argon exists in a latent form and whether it has an expressive character is at the heart of this debate. Modern linguists deny the existence of hidden argon.

A.T. According to Lipatov, "the creation of an artificial language requires a lot of work, even for a specialist". Therefore, the lower classes of society communicate in simple vulgar speech that is not specific to the rules of language. It is inappropriate to apply the laws of linguistics to the existing reality. Because it is not considered a means of communication and it is not functional. Group language is intended for more practical use. In general, it is a goal, not a tool. 
CURRENT RESEARCH JOURNAL OF PHILOLOGICAL SCIENCES 2(12):

146-150, December 2021

DOI: https://doi.org/10.37547/philological-crjps-02-12-28

ISSN 2767-3758

(C2021 Master Journals

Crossref do

gil Google

Accepted19th December, 2021 \& Published 24 ${ }^{\text {th }}$ December, 2021

Argon is a word that is common in the speech of thieves and gamblers and is not understood by the public. For example, quail (gun), molatbu (bar), hitola (with mouth), dego (quail), mud yakan (money), okrasni (move). Such words are used in part in fiction.

There are also views on argon as jargon. The 2volume explanatory dictionary of the Uzbek language contains the following sentences:

Argo $[\mathrm{r}<\mathrm{fr}]$ lingv. An artificial language specific to a social group that others do not understand; jargon. O'g'rilar argosy.

Argon (French. argot) the specific language of a particular professional or social group. Argon is a mixture of several language elements and, in many cases, a form of speech that is incomprehensible to others. Argon is used in speech to keep the subject of communication secret: 1) In the speech of thieves: mandarin (gold), akula (grid cutting device), kalamush ("falling" on one's loved ones), urkagan (experienced thief); In the speech of the prisoners: maymun (play), shobla (group of fraudsters), bashli (money), krokodil (scissors), lebed (heroin), ment (militiamen), xafa qilmoq (rape), pushka (pistol). Argotisms vary in different colonies, prisons, groups, and regions.

Argon is a conditioned word or phrase between people of a very narrow circle (group) of the same interests, occupations, and ages. They will not be understood by the general public. It does not have its own basic dictionary. Because there is a "tissue language" between a certain group, such words end when the group ends.

Argo (fr. Argot - "dialect") - a speech of a certain professional or social group, consisting of a specific word. Mas., yopmoq the word "end session" in student speech, flesh of the word fleshka in the style of, vinchestr of the word vint used in the style of slang is typical of speech. Argon manifests itself in the form of a mixture of several linguistic elements and, in many cases, speech incomprehensible to another. Argon does not have its own grammar. It is based on the grammar of the vernacular. Argon is used in speech for one of three purposes: 1) secrecy of opinion; 2) identification of the speaker; 3) for convenience.

Slang is a word that can only be understood by people of a certain social group. Slang is also a word used in the vernacular. Although slang does not indicate class stratification, such words are not understood by the general public. In this sense, slang is similar to slang.

The linguist gives the following examples according to his definition: From the argos of musicians and hafiz: Yakan (money), noyi (no), xanjar (abdomen), xit (hungry), hasut (bread), dax (in a good, correct sense).

From thieves: Loy (money), harif (owner of money or object of theft), shabash (give it to me), mandra or mura (bread), ligavi (police) tribe.

1. From the merchants' argos:

Sar or sari piyoz (thousand rubles), saru nimsar (one thousand five hundred rubles), kapara (six thousand rubles) and so on.

2. From thugs:

Zamri (Shut up or pause), atamri (speak or continue your previous work), shuxur or atan- da (escape), xamka (bread), deshevka (whistleblower, gossiper), rubay (eat) tribes.

When it comes to slang and slang, some scholars understand them as a single phenomenon, while others describe them as other phenomena (slang differs from slang in its solemnity). Some linguists say, "Jargon and slang pollute the language. The struggle for the purity, richness and perfection of 
CURRENT RESEARCH JOURNAL OF PHILOLOGICAL SCIENCES 2(12):

146-150, December 2021

DOI: https://doi.org/10.37547/philological-crjps-02-12-28

ISSN 2767-3758

(C2021 Master Journals

Crossref do

gil Google

Accepted19th December, 2021 \& Published 24 ${ }^{\text {th }}$ December, 2021

language also requires a struggle against jargon and slang". We would like to emphasize that nonliterary means, especially slang and jargon, enrich the literary language materially, live in speech as natural and necessary phenomena, and can be used for various purposes.

In general, the characteristics of slang are as follows:

1. Slang is a different, very narrow group of things and events that have a name in literary language.

2. Argons always have an expressive stylistic color.

3. Most slangs are transient, temporary, and then gradually or completely forgotten, or due to their emotional-stylistic color, they can be transferred from simple speech to general use, that is, to unlimited vocabulary.

Argon is used in speech to keep the subject of communication secret. For example, 1) in the speech of thieves: "mandarin" - gold, "shark" - a device for cutting the grill, "rat" - "falling" on his loved ones, "thief" - an experienced thief; 2) In the speech of the prisoners: "monkey" - play, "shobla" a group of fraudsters, "head" - money, "crocodile" scissors, "lebed" - heroin, "ment" - militiaman, "to offend" - to rape, "pushka" - pistol.

\section{Conclusion}

As you know, the history of language is an event related to the history of the people. If there is a change in the history of the people, it will be reflected in the language. Therefore, at different times, different words appear, some of them go out of use due to the requirements of the time, some words take on new meanings. In fact, slangs also form a group of words in the Uzbek dictionary. There are many different words in this group. Different people use such words in different languages. This means that certain groups use these words in a different sense, that is, for their own purposes.

The vocabulary used by social groups goes beyond its scope and expands its scope.

Argon is the language of a closed social group and it completely changes the commonly used phrases. In fact, the origin of slang goes back to slang, and it should be studied as an integral part of slang. Argons are more secretive than jargon. Therefore, they are more common in the speech of spies, criminals, thieves, drug addicts, prostitutes and other closed social groups who are considered to be the secret layers of society.

\section{REFERENCES}

1. Azizov 0 . Introduction to Linguistics. Tashkent. Teacher. 1996

2. Hodjiev A. Explanatory dictionary of linguistic terms. Tashkent. State Scientific Publishing House "National Encyclopedia of Uzbekistan" 2002

3. Jamolkhonov H. Modern Uzbek literary language. Tashkent. Interpretation. 2005

4. Mengliyev B. Mother tongue. Encyclopedic Dictionary. Tashkent. 2009

5. Pinxasov Ya. Modern Uzbek literary language. Tashkent. Teacher. 1969

6. Kilichev E. Modern Uzbek literary language. Bukhara. Bukhara University Publishing House. 1999

7. Rakhimov S., Umurkulov B. Modern Uzbek literary language. Tashkent. Teacher. 2003

8. Sayfullayeva R. Modern Uzbek literary language. Tashkent. 2010

9. Annotated dictionary of the Uzbek language. Volume II. I tom. Moscow. Russian Language Publishing House. 1981. -B. 632.

10. Annotated dictionary of the Uzbek language. 
CURRENT RESEARCH JOURNAL OF PHILOLOGICAL SCIENCES 2(12):

146-150, December 2021

DOI: https://doi.org/10.37547/philological-crjps-02-12-28

ISSN 2767-3758

(C)2021 Master Journals

Crossref doi 81 Google

Accepted19th December, 2021 \& Published 24th December, 2021

V tomlik. I tom. Tashkent. State Scientific Publishing House "National Encyclopedia of Uzbekistan". 2008

11. Akhmanova O.S. Dictionary of linguistic terms. - M .: CE, 1969

12. Lipatov A.T. Slang as a problem of sociolectics. Moscow. Publishing house
ELIPS. 2010

13. Morin M.K. Peterevnikova N.N. The stylistics of the modern French language. -Moscow. 1960

14. Safarov Sh. Pragmalinguistics. Tashkent. 2008 